является ее неотъемлемой частью и одновременно условием ее воплощения в жизнь, а сформированная национальная идентичность способствует консолидации гражданского общества.

$$
* * *
$$

1. Стратегия государственной национальной политики Российской Федерации на период до 2025 года (ред. от 06. 12. 2018 года). URL: http:/pravo.gov.ru/proxy/ips/?docbody=\&nd=102161949 (дата обращения 20.04.2021).

2. Тишков В.А. Российский народ: история и смысл национального самосознания. Институт этнологии и антропологии им. Н.Н. Миклухо- Маклая РАН. - М.: Наука, 2013. - 649 с.

3. Ромашкин Т.В. Межэтническое взаимодействие в контексте российской идентичности // Актуальные проблемы гуманитарных и общественных наук. 2016. № 9-10 (66-67) - С.55-61

4. Мухаметшин Фарит Новый гуманизм как мировоззренческая основа культуры мира // Международная жизнь. 2012. №1. URL: https://interaffairs.ru/jauthor/material/600 (дата обращения 20.04.2021).

5. Сартр Ж. П. Бытие и ничто: Опыт феноменологической онтологии / Сартр Ж. П. M., 2000. URL: http://yanko.lib.ru/books/philosoph/sartre=butie_i_nichto=ann.htm\#_Toc130721406 (дата обращения 20.04.2021).

6. О войсках национальной гвардии Российской Федерации. Федеральный закон N $226-\Phi 3$ от 03.07.2016 (ред. от 31.07.2020). URL: www.pravo.gov.ru (дата обращения 20.04.2021).

7. Бердяев Н.А. О русском национальном сознании. URL: http:/www.spasi.ru/biblt/berd6.htm (дата обращения 20.04.2021).

8. Бьюкенен Патрик Дж. Смерть Запада / Бьюкенен Патрик Дж. URL: https://azbyka.ru/fiction/smertzapada/ (дата обращения 20.04.2021).

\title{
Упоров И.В., Долгов А.А. \\ Институт государственной (гражданской) службы в России (период до 1725 года): истоки и развитие
}

Краснодарский университет МВД России (Россия, Краснодар)

doi: 10.18411/lj-06-2021-293

\section{Аннотация}

Рассматриваются основные тенденции в формировании и развитии института государственной гражданской службы в истории России в период до окончания правления Петра I. Анализируются нормы правовых актов, научные труды по заявленной теме. Отмечается, что в Древнерусском государстве на первый план выходила военная служба, и такой приоритет сохранялся довольно долго. Постоянные должности гражданской службы (в приказах, земских учреждениях и др.) стали создаваться только в Московском государстве, тогда же они стали закрепляться в законодательстве (например, Соборное уложение 1649 г.), но без определенной системы. В известных указах Петра I этот недостаток был преодолен, и с того времени институт гражданской службы стал непременным атрибутом государственного аппарата.

Ключевые слова: государство, гражданская служба, приказы, должности, указы, полномочия, общество, закон.

\section{Abstract}

The main tendencies in the formation and development of the institution of the state civil service in the history of Russia in the period before the end of the reign of Peter I are considered. The norms of legal acts, scientific works on the stated topic are analyzed. It is noted that military service came to the fore in the Old Russian state, and this priority remained for quite a long time. Permanent positions of the civil service (in orders, zemstvo offices, etc.) began to be created only in the Moscow state, at the same time they began to be 
enshrined in legislation (for example, the Cathedral Code of 1649), but without a specific system. In the well-known decrees of Peter I, this deficiency was overcome, and since that time the institution of the civil service has become an indispensable attribute of the state apparatus.

Keywords: state, civil service, orders, positions, decrees, powers, society, law.

Институт государственной (гражданской) службы, как известно, на системном уровне сформировался при Петре I. Однако, и как любое другое социальное явление, такая служба имеет свои истоки, предпосылки. Например, в Древнерусском государстве госслужба связывалась с государственной военной службой и функционировала в системе вассалитета. И именно о военной (ратной) службе идет речь во многих трудах по истории Древней Руси (авторы Н.А. Максимова, П.М. Морхат, Д.С. Лихачев, М.Б. Свердлов, Л.В. Миникова, А.В. Серегин, Я.Н. Щапов, Н.М. Золотухин и др.). Как отмечает А.В. Шободаева, в Древнерусском государстве уже функционировал достаточно разветвленный государственный аппарат, но легитимность его какими-то специальными государственными актами подтверждена не была: отсутствовала официальная лестница чинов, их должностные инструкции, закрепленные привилегии, боярство еще не имело сословной корпоративности и замкнутости [1, с. 55].

В средневековье (XV-XVII вв.) стало происходить корректировка в понимании и значимости государственной службы, учитывая, что на жизнь общества в большей степени стали влиять уже сложившиеся традиции, нравы, обычаи, которые закреплялись законодательных актах [2, с. 177]. В правовых нормах находило отражение позитивная моральная оценка служилого дела [3, с. 72]. В России в тот период функционировали следующие основные органы власти и управления: великий князь (царь); Боярская дума как постоянный совещательный орган при государе, участвовавший в законодательстве, управлении, судебной деятельности; Земские соборы, в основном участвовавшие в решении вопросов внешней и внутренней политики, законодательства, финансов, государственного строительства; приказы, возникшие из личных поручений государя и ставшие развитием дворцовых ведомств (постепенно приказное управление охватило все отрасли государственного управления); органы местного управления. Это была государева служба - так она расценивалась и правительством, и сословными группами, прежде всего дворянством [3, с. 73]. При этом данная служба считалась прежде всего службой государю, а не государству [4, с. 117] (преодолеть понимание государства как великокняжеской вотчины, по мнению В.О. Ключевского, удалось только в начале XVII в. [5, с. 48]). Военная служба по-прежнему оставалась одним из важнейших государственных институтов и находилась в приоритет, соответственно военное управление отличалось более высоким уровнем системности.

Вместе с тем тогда начинают формироваться организационно-правовые основы и гражданской службы, о чем свидетельствовало создание специального функционально-отраслевого, приказного управления в различных сферах деятельности государства, появление таких должностей, как дворецкие, дьяки и др., соответственно расширялась социальная база при формирования государственных гражданских служащих, когда таковыми могли быть лица не только высших сословий. Так, в Московском государстве, в связи с новыми задачами, вставшими перед великодержавной канцелярией, в особую должность выделились казначеи, ведавшие финансовыми и внешнеполитическими делами; дьяки государевой казны исполняли решения верховной власти, специализируясь на выполнении определенных поручений: дипломатических, финансовых, военных, ямских, правоохранительных и т.д. Такой подход позволил сформировать к середине XVI в. систему органов управления с 
функциональным разделением дел, пришедшим на смену территориальным органам на основе приказов.

И уже на рубеже XVI-XVII вв. те же приказы стали важнейшей составляющей механизма централизованного государства, которые непосредственно и при этом от имени государства выполняли его функции, для чего они наделялись соответствующими полномочиями. Общее число приказов, считая временные, к середине XVII в. достигло шестидесяти. Работавшие в них лица как раз и составляли ядро нарождающейся государственной гражданской службы, в частности, об этом свидетельствует появление постоянных профессиональных должностей. В свою очередь, возросшее количество узковедомственных приказов вызвало необходимость принятия мер по упорядочению самой госслужбы. В этом контексте, например, были выделены органы с компетенцией, охватывающей деятельность других органов власти и управления, в частности, это касалось расходов на жалованье служилых, содержание помещений, где они располагались, канцелярские происхождение и т.д., чем ведал Приказ Большого прихода; Разрядный приказ ведал учением и назначением на службу служилых людей «по отечеству», то есть дворянства, определял их количество и место службы (военной и гражданской); Поместный приказ осуществлял фактическое наделение землей, регистрировал сделки на земли, выступал в качестве судебного учреждения по спорам, связанным с земельными делами и побегами крестьян; Ямской приказ ведал транспортом для казенных надобностей, который обслуживал передвижение военных и дипломатических гонцов, иностранных послов, служащих государственных учреждений [6, с. 84].

В системе государственного управления приказы, как органы государственного управления, представляли собой средний уровень госаппарата и выполняли как административно-управленческие, так и судебные функции (в сфере своей деятеьности). Они возглавлялись судьями, назначаемыми из бояр, но основную работу выполняли дьяки - служилые, обладавшие грамотой, понимавшие суть деятельности приказов и имевшие соответствующие навыки [7, с. 27]. Кроме судей и дьяков, в приказной деятельности были задействованы старшие и младшие приказные служащие, причем последние зачастую жили за счет заявителей, поскольку их служб труд не всегда не оплачивался государством, и в этом смысле данную категорию работников приказов, очевидно, нет оснований причислять к государственным гражданским служащим. Как отмечается в литературе, упомянутый выше Разрядный приказ вел «личные дела» 22-23 тыс. человек, но так как тогда не было строгого различия между военной и гражданской службой, то из представляемых списков формировалось служивое сословие назначений в самые разные ведомства; при это уже обозначались и аналоги чинов - так, при назначениях принимались в расчет обычно следующие сведения: родословная («порода») кандидата, его чиновность (служебный титул) и разрядность (предыдущие должности) [8, с. 110].

Следует заметить, что реальное положение института государственной службы, которая еще не делилась на гражданскую и военную, опережало нормативно-правовое регулирование этих отношений, если иметь в виду первую половину XVII в. В этом отношении нельзя не назвать Соборное уложение 1649 г., где законодатель стал регулировать отдельные вопросы государственной службы, указывая, в частности. на такие приказы, как Посольский приказ, Разрядный приказ, Стрелецкий приказ, Земский приказ, Разбойный приказ, Судный приказ, Поместный приказ, Монастырский приказ и др. В этом акте находились также нормы о полномочиях служилых некоторых приказов, об ответственности служилых за мздоимство и другие нарушения. И, таким образом, государственная гражданская служба получила свое законодательное закрепление, хотя, конечно, еще не на системном уровне. Как отмечает П.М. Морхат, к тому времени высший слой государственных служащих России формировался в рамках института, который назывался Государев двор. Его представители занимали высшие и 
средние командные должности в армии, возглавляли центральные и местные органы власти, были полновластными хозяевами в подчиненных им территориях. Право занимать определенные государственные должности принадлежало аристократическим родам и каждому роду в специальном разряде было четко определено его место. Отсюда и название системы назначений на высшие государственные посты местничество. Эта система негативно сказывалась на эффективности управленческой деятельности, привела не только к возникновению номенклатуры, но и через упрочение кастовости слоя государственных служащих - к неэффективности и некомпетентности большей части чиновничества [9, с. 43]. Заметим, что данное явление в негативном его аспекте до сих не исчезло из практики государственной службы в России. В целом, если иметь в виду общую классификацию госслужащих, то к тому времени (XVII в.) уже обозначилось разделение на чиновничество (служивый класс), и номенклатуру (разрядные списки).

Между тем по мере развития российской государственности расширялось и количество служащих. Если в 1640 г. таковых в центральном аппарате насчитывалось более полтора тысяч служащих, то спустя полвека уже около пяти тысяч [10, с. 6], а это практически трехкратное увеличение. Вместе с тем нельзя не отметить, что такой рост имел объективную основу и связывался с увеличением территории государства, а также с традицией доминирования государства над обществом, то есть развитием абсолютизма. В целом же в XVII вв. были сформированы основы государственной гражданской службы, и процесс ее совершенствования не останавливался. Так, в 1682 г. решением Земского собора было отменено местничество. В литературе отмечается, что в результате началось преобразование государственной службы: если ранее происхождение обусловливало право получение чина, то теперь сам чин открывал служилому человеку дорогу в высшее общество. Появилось стремление привести систему чинов в соответствие с требованиями времени. Однако попытка изменить систему чинов предпринята в проекте Уставе о служебном старшинстве бояр, окольничих и думных людей оказалась безуспешной, чины по-прежнему получали по родовому признаку [11]. Поэтому, как отмечалось, системности и полноты регулирования государственной гражданской службы в Московском государстве еще не хватало.

И в этом смысле, конечно, огромная заслуга принадлежит Петру I, который разработал и систематизировал правовые акты, определявшие институт государственной службы. Так, в Указе от 4 июня 1719 г. был издан Указ о пресечении местничества, где, в частности, предписывалось, что «старые разряды вечно оставлены, а вместо того славное безместие ... ради всяких настоящих интересов» [12], соответственно Указ требовал прекращения ссылок на разрядные списки, а нарушители сего «будут истязаны и наказаны». Через две недели был издан Указ о присяге служилых [13].

Указом от 13 февраля 1720 г. был создан Главный магистрат - центральное государственное учреждение в России, основанное в Санкт-Петербурге, с целью централизации управления делами посадского населения на правах коллегии. Через год, в январе 1721 г., был утвержден «Регламент, или Устав Главного магистрата» [14], определивший его состав и функции. Согласно указу, новый орган был призван «ведать всех купецких людей судом и о их делах доносить в Сенат, и рассыпанную сию храмину паки собрать». По Регламенту, горожане делились на «регулярных граждан» (входивших в гильдии и цеха) и «подлых» (находившихся «в наймах» и на «чёрных работах»). Порядок жизни тех и других регулировался учреждавшимися на местах городовыми магистратами. Главный магистрат руководил городовыми магистратами, рассматривал апелляции на их судебные решения, контролировал распределение финансов в городах, в том числе, сбор податей. Довольно быстро предусмотренные этим актом городские магистраты - эти сословные органы местного управления 
торгово-промышленным населением - стали главными органами бюрократического аппарата петровской империи, поскольку опирались, хотя и в ограниченной степени, на сословное представительство на местах. Были приняты и другие указы, уточняющие различные аспекты государственной службы. Главный магистрат был упразднен в 1727 г. указом Верховного тайного совета и временно заменен Ратушей, вновь создан в мае 1743 г. как Контора Главного магистрата, но переведен в Москву (Елизавета Петровна восстановила его как одно из установлений Петра I). По предписанию Сената Главный магистрат стал подчиняться губернским властям и полиции. С 1775 г. он стал почти исключительно судебным учреждением, рассматривал уголовные и гражданские дела лиц из купеческого и мещанского сословий. Екатерина II окончательно ликвидировала Главный магистрат в 1782 г.

24 января 1722 г. Петр I утвердил знаменитый Табель о рангах - закон о порядке государственной службы в Российской империи (чины по старшинству и последовательность чинопроизводства) [15]. Помимо этого, были приняты и другие законы, отдельные нормы которых также регулировали вопросы государственной службы. Следует отметить, что этот закон не разъяснял само понятие «чин», в силу чего одни историки последний рассматривали буквально и лишь в системе чинопроизводства, другие же - как ту или иную должность. Мы полагаем, что в названиях чинов имели место элементы собственно должности и звания. Так, в в IX классе в разделе статских чинов перечислены следующие должности: «Титулярный советник; воинских двух, иностранной коллегий секретари; обер-рентмейстер в губерниях, полицеймейстер в резиденции, бургомистры от магистрата в резиденции быть непременным, лантрихтеры в провинциях, профессоры при академиях, докторы всяких факультетов, которые в службе обретаются, архиварии при обоих государственных архивах, переводчик и протоколист сенатские, казначеи при монетном деле, асессоры в надворных судах в резиденции, директоры над пошлинами в портах» [15]. Для VIII класса в Табели в соответствующей графе перечислены следующие должности: «Ундер стат галтер в резиденции, экономии галтер, регирунс раты в губерниях, обер директор над пошлинами и акцизами в резиденции, обер лантрихтеры в резиденции, президент в магистрате в резиденции, обер комиссары в коллегиях, асессоры в коллегиях, обер правиант мейстер в резиденции, обер секретари в протчих коллегиях, секретари в Сенате, обер берг мейстер, обер валдейн, обер минц мейстер, надворный советник, надзиратель лесов, воеводы» [15]. Как видно, указываются не только должности, но и учреждение, в котором должен служить обладатель соответствующего класса. Это подтверждается и 4-м пунктом второй части законодательного акта: «Под равным штрафом, не имеет никто рангу себе требовать, пока он на свой чин надлежащего патента показать не имеет» [15].

Табель о рангах, определяя место в иерархии государственной службы, в некоторой степени давал возможность выдвинуться талантливым людям из низших сословий. «Дабы тем охоту подать к службе и оным честь, а не нахалам и тунеядцам получать» - гласила одна из описательных статей закона. При этом Табель проводил грань между военной и гражданской государственной службой, отдавая приоритет военной службе - военные чины объявлялись выше соответствующих им гражданских и даже придворных чинов. Такое старшинство давало преимущества военным чинам в главном - переходе в высшее дворянское сословие. В литературе подчеркивается, что что издание Табели о рангах самым тесным образом было связано с кардинальными изменениями всей правовой системы, системообразующее значение в которых имели изменения соотношения обычая и закона как источников права. Закон de jure признавался единственным источником права. Абсолютный монарх был волен издавать законы, которые должны были выполнять все, в том числе и верховная власть. В этих условиях вполне логичным являлось стремление подчинить государственную службу законодательному регулированию, причем достаточно подробному [16, с. 53]. Другой особенностью является то, что Табель о рангах устанавливал механизм постепенного 
продвижения чиновника по служебной лестнице. В целом Табель о рангах стал основным правовым актом, заложившем основу государственной службы в России на почти двести лет.

\section{$* * *$}

1. Шободаева А.В. Формирование корпуса государственных служащих и их нравственнопрофессиональная характеристика (Киевский период) // Известия Иркутской ГЭА. 2012. № 1. С. 55-56.

2. Щапов Я.Н. О системах права в Древней Руси // История СССР. 1987. №5. С. 175-181.

3. Синицина Н.В. Идея законности в русской общественной жизни и об-щественной мысли конца первой трети XVI в. // Общество, государство, право России и других стран Европы. Нормы и действительность. Ранний и развитой феодализм. М., 1983. С. 71-76.

4. Талина Г. С чего начиналась государственная служба // Государствен-ная служба. 1999. № 3. С. 117.

5. Ключевский В.О. Сочинения. В 9 т. Т. 3. М., 1993. С. 48.

6. Демин А.А. Государственная служба. М., 2007. С. 84.

7. Ерошкин Н.П. История государственных учреждений дореволюцион-ной России / Под ред. А.Е. Иванова, А.Д. Степанского. 5-е изд., доп. М., 2008. С. 27.

8. Семенникова Л.И. Цивилизационные парадигмы в истории России // Общественные науки и современность. 1998. № 3. С. 110.

9. Морхат П.М. Взаимодействие правовых и моральных норм в сфере государственной службы России: дис. ... канд. юрид. наук. М., 2003. 196 с.

10. Павленко Н. И. У истоков российской бюрократии // Вопросы исто-рии. 1989. № 12. С. 6.

11. Морхат П.М. Государственная служба в России: опыт реформ Петра I и современность // Республиканский портал государственной слубы https://daggossluzhba.ru/novosti/publikacii/dlja-chtenija-po-vyhodnym-gosudarstvenna.html (дата обращения: 30.05. 2021 г.).

12. Указ от 04.06. 1719 г. «О пресечении местничества и о порядке стар-шинства Коллежских Членов» // ПС3-1. № 3384.

13. Указ от 19.06. 1719 г. «О присяге на верность службе» // ПСЗ-1. № 3395.

14. Регламент, или Устав Главного магистрата от 16.01.1721 г. // ПС3-1. № 3708.

15. Табель о рангах всех чинов Воинских, Статских и Придворных, которые в котором классе чины; и которые в одном классе, те имеют по старшинству времени вступления в чин между собою, однакож Воинские выше прочих , хотя бы и старее, кто в том классе пожалован (далее - Табель о рангах) от 24 января 1722 г. // ПС3-1. № 3978.

16. Архипова Т.Г., Сенин А.С., Румянцева М.Ф. История государственной службы в России XVIII XX вв. М.,2001. С. 53.

\section{Янова М.В. \\ Современный внешнеполитический курс РФ за мир, безопасность и устойчивое развитие в борьбе с экстремизмом и терроризмом в условиях преодоления угроз человечеству}

БНУ РК «Институт комплексных исследований аридных территорий» (Россия, Элиста)

doi: $10.18411 / l j-06-2021-294$

\section{Аннотация}

В статье рассмотрены важнейшие направления внешнеполитического курса РФ в конце XX - начала XXI столетия.

Показана общая характеристика деятельности структур государственной власти по данной проблеме, формы борьбы с экстремизмом и терроризмом, история формирования терактов за рубежом.

Ключевые слова: Экстремизм, терроризм, внешнеполитический курс РФ, глобальные войны, вооруженные конфликты, мир и безопасность РФ, торговля оружием, приоритеты нравственности мира. 